\title{
Biological and Molecular Studies on an Egyptian Potyvirus Isolate from Hyocyamus muticus $\mathrm{L}$.
}

\author{
Reham $^{1 *}$ M. Elbaz, E.T. Abd El-Salam ${ }^{2}$, M.E Osman ${ }^{1}$ and \\ Asmaa F. Abd E-Monem ${ }^{1}$ \\ ${ }^{1}$ Botany and Microbiology Department, Faculty of Science, \\ Helwan University. and ${ }^{2}$ Botany and Microbiology Department, \\ Faculty of Science, Cairo University, Cairo, Egypt.
}

\begin{abstract}
NEW isolate of potyvirus was isolated from naturally-infected henbane plants (Hyocyamus muticus L.) collected from the farm of Faculty of Pharmacy, Cairo University in January 2013. The naturally infected henbane plants exhibited severe mosaic, rugosity, blistering and malformation. Thermal inactivation point, dilution end point and longevity in vitro of virus isolate were found to be $65{ }^{\circ} \mathrm{C}$, $10^{-4}$ and 4 days, respectively. Electron micrograph of partial purified virus negatively stained with $2 \%$ phosphotungestic acid revealed the presence of filamentous viruses with size 1440 X14.3nm. Total RNA was extracted from infected henbane plant. Comparative nucleotide sequence analysis for virus showed a high degree of similarity $(62 \%)$ with four poty viruses accessions (EU482153: Potato virus $\mathrm{Y}$ isolate Foggia, KF850513: Potato virus $\mathrm{Y}$ isolate M3, AM 184113: Henbane mosaic virus partial gene for polyproteinPHYS/H isolate, AY166867: Potato virus Y strain N isolate). The virus isolate was published in GenBank with accession number KM497011.
\end{abstract}

Keywords: Potyvirus, Electron microscopy, Comparative Nucleotide sequence.

Potyvirus is the largest plant viruses genus causing significant losses in a wide range of crops (King et al., 2011; Revers and García, 2015) that is accounted for $40 \%$ of losses (Larsen et al., 2003; Yamamoto and Fuji, 2008). Horvath et al. (1988) showed that HMV infection has increased due to increasing the populations of Datura stramonium due to their application of nitrogen-containing fertilizers. Saha et al. (1997) reported that a mechanically transmissible filamentous virus causing severe mosaic with leaf blisters and malformation of Datura metel was identified as a strain of henbane mosaic potyvirus (HMV-Da) depending on its host range and electron-microscopy. This virus was restricted to species of Solanaceae and induced systemic symptoms in Nicotiana spp. and Hyocyamus niger but it was symptomless to Lycopersicon esculentum, Capsicum annuum and Solanum spp. In addition, HMV-Da particle was measured as 795 X $12 \mathrm{~nm}$.

The genes of potyviruses that encoding a different proteins such as $\mathrm{N}$ terminal protein, helper component protease, protein $\mathrm{P} 3,6 \mathrm{KD}$ protein, cytoplasmic 
inclusion protein, $6 \mathrm{KD}$ protein 2, genome-linked protein, nuclear inclusion protein A, nuclear inclusion protein B and coat protein (Riechmann et al., 1992). Shukla et al. (1994) found that the genome of potyviruses is positive sense single stranded RNA of 10000 nts with a VPg (virus protein genomic linked).

This investigation was carried out to identify a new Egyptian potyvirus isolated from naturally-infected Hyocyamus muticus L. plant showing mosaic, leaf blistering and malformation symptoms. Also, host range, particle size and morphology; in vitro properties as well as partial sequencing of the virus is olate were studied.

\section{Materials and Methods}

Source of the virus isolate

Fifteen infected henbane plants were collected in January 2013from the Experimental Farm of Faculty of Pharmacy, Cairo University. The plant samples were kept in sterile plastic bag then maintained at $-20^{\circ} \mathrm{C}$ for further study.

Detection of virus isolate by diagnostic plants

Three replica of each diagnostic plant for virus infecting henbane (Chenopodium amaranticolor, Ch. quinoa, Cucumis sativus, Datura stramonium, Nicotiana glutinosa, N. rustica, N. tabacum cvs. White Burley and Samsun, Solanum demissum and S. tuberosum) were selected according to Smith (1972). The diagnostic plants were grown under greenhouse conditions at Botany and Microbiology Department, Faculty of Science, Helwan University, Cairo, Egypt. One gram of naturally infected-henbane leaves was ground as a source of virus. The diagnostic plants were inoculated. Controls of corresponding plants were inoculated with the extraction buffer only. The inoculated plants were kept at moderate temperature $\left(25-28^{\circ} \mathrm{C}\right)$ in an insect proof greenhouse until external symptoms appeared.

Virus isolation and propagation

Infectious crude sap prepared from the infected henbane plants which gave positive results with diagnostic hosts and then mechanically inoculated on $S$. demissum for developing single local lesion. The local lesion produced was ground and used for the inoculation on healthy $H$. muticus seedlings leaves as a propagative host. The inoculated $H$. muticus plants were kept in an insect proof greenhouse until external symptom appeared.

\section{Biological characters}

Host range and symptomatology

Twenty seven seedling plants belonging to 6 families (Asteraceae, Chenopodiaceae, Crucifrae, Cucurbitaceae, Fabaceae, and Solanaceae) were maintained in an insect proof greenhouse. Plants were mechanically inoculated with virus-infected sap. The inoculated plants were kept in an insect proof greenhouse conditions until symptoms appeared.

In vitro properties

Egypt. J. Bot., Vol. 56, No. 2 (2016) 
In vitro properties of the isolated virus [thermal inactivation point (TIP), dilution end point (DEP) and longevity in vitro (LIV)] were performed on leaves of $S$. demissum by using infectious crude sap obtained from virus infected $H$. muticus plants. The inoculated plants were kept in an insect proof greenhouse.

Partial purification of virus isolate: Virus purification was done according to modified method of Steere (1956). One hundred gram of fresh infected henbane leaves were homogenized in $0.1 \mathrm{M}$ phosphate buffer $\mathrm{pH} 7.0$ containing mercaptoethanol and clarified by adding cold $n$-butanol: chloroform (1:1). The upper aqueous phase was centrifuged at $6000 \mathrm{rpm}$ for $30 \mathrm{~min}$. The clarified supernatant was collected, concentrated by $4 \% \mathrm{NaCl}$ and polyethylene glycol and then ultra-centrifuged at $40.000 \mathrm{rpm}$ for $90 \mathrm{~min}$. The pellet was suspended in phosphate buffer $\mathrm{pH} 7$ and centrifuged at $6000 \mathrm{rpm}$ for $20 \mathrm{~min}$. Pellet was discarded and the resulted supernatant was the partially purified virus.

Calculation of virus concentration: Partially purified virus preparations were measured at range 200-300 $\mathrm{nm}$ wave length using ultraviolet spectrophotometer (Jasco, Model V-630, serial Noc285061148, Physics lab, Faculty of Science, Helwan University) in order to evaluate purity and estimate the concentration of the partially purified virus using equation as mentioned by Noordam (1973).

Virus concentration was estimated spectrophotometrically using an extinction coefficient of a potyvirus 2.5 (Saha et al., 1997).

Virus morphology: The partial purified virus particles were negatively stained by $2 \%$ phosphotungestic acid $\mathrm{pH}$ 6.8. The grid air dried then was examined using Jeol-Jem 1010 Transmission Electron Microscope (TEM), The Regional Center of Mycology and Biotechnology, Al-Azhar University.

\section{Molecular characterization \\ Primer selection}

Three oligonucleotide potyvirus primers were designed according to the coat protein nucleotide sequences of potyvirus published in National Center for Biotechnology Information (NCBI). The potyvirus primers were HMV [30F20 (+)5'-ACC ACT GAA GCA AAC CGA GA-3'\& 788R20 (-)5'-CAT CTG GCG AAC ACC TAG CA-3'], Potato virus X (PVX) [87F22 (+)5'-CAG GGC TAT TCA CCA TAC CAG A-3' \& 652R20 (-)5'-TTC CTG TGA TGC GGC CCC TA-3'] and Potato virus Y (PVY) [21F20 (+)5'-GCA GGA GGA AGC AAC AAG AA-3'\& 734R22 (-)5'-GGT GGT GTG CCT CTC TGT GTT C-3'].

\section{Total RNA extraction}

The total RNA was extracted from $40 \mathrm{mg}$ of fresh tissue of virus infected henbane leaves using Gene JET RNA Purification Kit (Thermo Scientific \#K0731) with $300 \mu 1$ Lysis Buffer. 
RT-PCR was performed by RevertAid First Strand cDNA Synthesis Kit (Thermo Scientific K1621) according to Malek et al. (2000).

\section{Amplification of cDNA}

To perform specific PCR amplification for the virus coat protein sequence RNAs, the primer set of HMV, PVX and PVY based on conserved and virus specific sequences to amplify $\sim 778 \mathrm{bp}, 585 \mathrm{bp}$ and $735 \mathrm{bp}$ fragments respectively from coat protein length virus RNA. PCR was performed by Dream Taq DNA Polymerase kit (Thermo Scientific EP0702). The amplification was carried out using Veriti 96-Well Thermal Cycler. The initial denaturation cycle of the DNA was performed at $95^{\circ} \mathrm{C}$ for $5 \mathrm{~min}$ followed by 35 cycles of denaturation at $95^{\circ} \mathrm{C}$ for $45 \mathrm{sec}$, annealing at $56^{\circ} \mathrm{C}$ for $45 \mathrm{sec}$ for HMV reaction, $59.4{ }^{\circ} \mathrm{C}$ for PVX reaction and $56.3{ }^{\circ} \mathrm{C}$ for PVY reaction. The extension was done at $72^{\circ} \mathrm{C}$ for $60 \mathrm{sec}$ while a single trailing cycle of long extension at $72^{\circ} \mathrm{C}$ for 10 min was carried out in order to ensure flush ends on the DNA molecules. Finally, the amplified DNA was electrophoresed on $1 \%$ agarose gel and photographed using gel documentation system.

\section{Sequencing}

The purified PCR product was sequenced in two directions using high throughput Applied Biosystems 3730XL sequencers at Macrogen sequencing service, Korea.

\section{Similarity and alignment analysis}

The resulting nucleotide sequence of DNA was analyzed by using DAMANversion 5.2.9. The phylogenic relationship and alignment analysis of viral coat protein gene sequences were compared to those of the GenBank and EMBL databases by advanced BLAST (Megablast) searches from the National Center for Biotechnology Information (NCBI).

\section{Results}

Detection of the virus isolate by diagnostic hosts

Fifteen samples from naturally infected henbane plants (Hyocyamus muticus L.) exhibited viral symptoms on their leaves including severe mosaic, rugosity, blistering and malformation (Fig.1). These samples were mechanically inoculated on diagnostic hosts for viruses - infecting henbane and showed chlorotic local lesion with necrotic center appeared on inoculated leaf of Chenopodium amaranticolor, mosaic symptoms appeared on Datura stramonium and Nicotiana tabacum cv. White Burley. N. tabaccum cv. Sumsun showed necrotic lesions then systemic mosaic appeared on N. glutinosa. Chloresis then leaf malformation appeared on $N$. rustica, necrotic local lesions appeared on $S$. demissum and Solanum tuberosum. Moreover, no symptoms appeared on $C h$. quinoa and Cucumis sativus. 

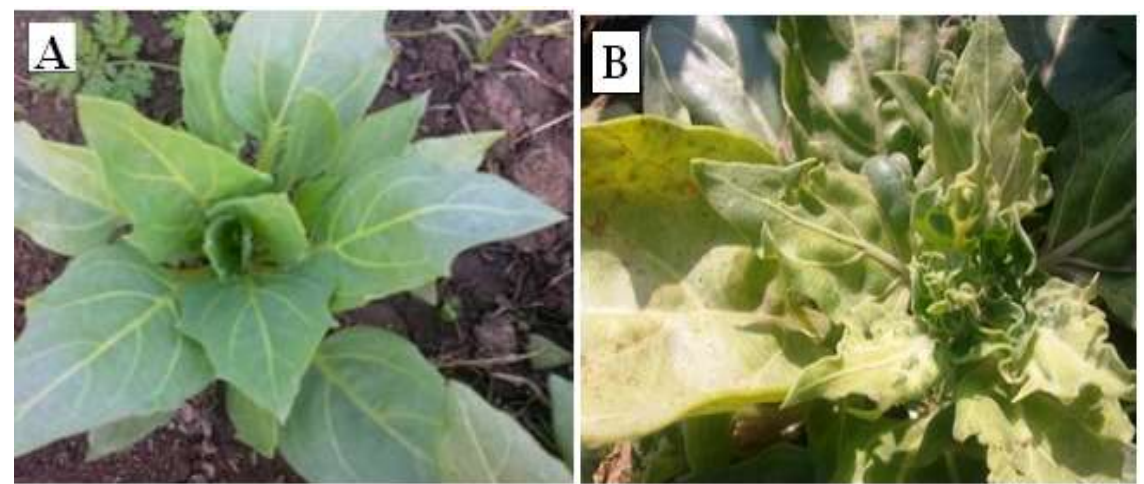

Fig.1. Hyocyamus muticus L., (A) healthy and (B) naturally-infected plant showing severe mosaic and blistering.

Isolation and propagation of virus isolate

The virus isolate was inoculated into Solanum demissum plant. After 6 days post-inoculation, necrotic local lesions (pin point) appeared. Single local lesion was separated and used for inoculation of healthy S. demissum plant. The same type of local lesion appeared. These local lesions were used to inoculate Hyocyamus muticus L. as a propagative host. After 1 week post-inoculation, vein clearing and mild mosaic appeared then turned into severe mosaic after 2 weeks (Fig. 2).

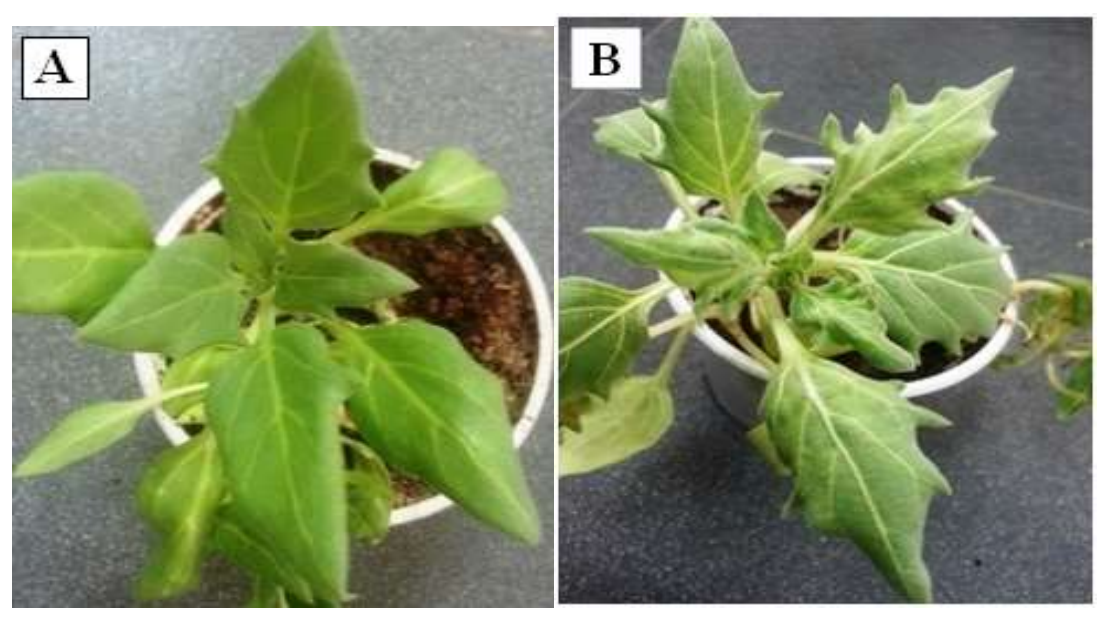

Fig 2. Hyocyomus muticus L., (A) healthy and (B) infected- plant showing sever mosaic symptoms

Host range and symptomatology

Virus is olate was tested on 27 plant species belonging to 6 families: Asteraceae, Chenopodiaceae, Crucifrae,_Cucurbitaceae, Fabaceae, and Solanaceae. 
From tested plants, 14 species reacted with different responses with virus isolate. These plants were Capsicum annuum, Chenopodium amaranticolor, Datura metel, D. stramonium, H. muticus, Lycopersicon esculentum, Nicotiana glutinosa, N. rustica, N. tabaccum cv. Kntaky, N. tabaccum cv. White Burely, $N$. tabaccum cv Samaun, Petunia hybrida, Solanum demissum and S. tuberosumas shown in Table 1. While the other 13 species exhibited no symptoms; these plants were: Brassica alba, B. nigra, Ch. quinoa Cucumis sativus, Cucurbita pepo, Glycine max, N. tabaccum cv. Kg23, N. tabaccum cv. Italy, N. glauca, Phaseolus vulgaris, Vicia faba, Vign aunguiculata and Zinnia elegans.

TABLE 1. Symptoms produced by virus isolate on different hosts.

\begin{tabular}{|c|c|c|}
\hline Plant family & Plant species & Symptoms \\
\hline Chenopodiaceae & Ch. amaranticolor & $\begin{array}{l}\text { Circular chlorotic local lesions with necrotic } \\
\text { center appeared after } 4 \text { days post-inoculation. }\end{array}$ \\
\hline \multirow{13}{*}{ Solanaceae } & C. annuum & $\begin{array}{l}\text { Vein necrosis appeared after one week post- } \\
\text { inoculation then crinkle and malformation } \\
\text { after } 2 \text { weeks developed. }\end{array}$ \\
\hline & D. metel & $\begin{array}{l}\text { Necrotic local lesions after } 5 \text { days post- } \\
\text { inoculation appeared then crinkle and } \\
\text { systemic mild mosaic appeared on new leaves } \\
\text { after two weeks post-inoculation. Finally } \\
\text { after } 3 \text { weeks, it was turned into severe } \\
\text { mosaic, blistering and malformation. }\end{array}$ \\
\hline & D. stramonium & $\begin{array}{l}\text { Systemic mosaic symptoms developed after } \\
10 \text { days post-inoculation. }\end{array}$ \\
\hline & H. muticus & $\begin{array}{l}\text { Vein clearing, mild mosaic appeared after } 1 \\
\text { week post-inoculation then turned into sever } \\
\text { mosaic after } 2 \text { weeks. }\end{array}$ \\
\hline & L. esculentum & $\begin{array}{l}\text { Chlorotic local lesions appeared after } 5 \text { days } \\
\text { post-inoculation then mosaic and crinkle } \\
\text { developed after } 3 \text { weeks. }\end{array}$ \\
\hline & N. glutinosa & $\begin{array}{l}\text { Necrotic local lesion appeared after } 1 \text { week } \\
\text { post-inoculation. Then systemic mosaic } \\
\text { symptoms, leaf malformation and stunting } \\
\text { developed after } 2 \text { weeks. }\end{array}$ \\
\hline & N. rustica & $\begin{array}{l}\text { Chlorosis appeared after } 12 \text { days post- } \\
\text { inoculation then developed to crinkle and } \\
\text { malformation after } 3 \text { weeks. }\end{array}$ \\
\hline & $\begin{array}{l}\text { N.tabaccum cv. } \\
\text { Kntaky }\end{array}$ & $\begin{array}{l}\text { Mild mosaic appeared after } 3 \text { weeks post- } \\
\text { inoculation. }\end{array}$ \\
\hline & $\begin{array}{l}\text { N. tabaccum cv. } \\
\text { White Burely }\end{array}$ & $\begin{array}{l}\text { Systemic mosaic symptoms and crinkle } \\
\text { appeared after } 2 \text { weeks post-inoculation. }\end{array}$ \\
\hline & $\begin{array}{l}\text { N. tabaccum cv. } \\
\text { Samaun }\end{array}$ & $\begin{array}{l}\text { Systemic mosaic symptoms appeared after } 20 \\
\text { days post-inoculation. }\end{array}$ \\
\hline & P. hybrida & $\begin{array}{l}\text { Mild mosaic appeared after } 3 \text { weeks post- } \\
\text { inoculation. }\end{array}$ \\
\hline & S. demissum & $\begin{array}{l}\text { Necrotic local lesions appeared after } 6 \text { days } \\
\text { post-inoculation. }\end{array}$ \\
\hline & S. tuberosum & $\begin{array}{l}\text { Necrotic local lesions appeared after 5-6 days } \\
\text { post-inoculation. }\end{array}$ \\
\hline
\end{tabular}

Egypt. J. Bot., Vol. 56, No. 2 (2016) 
In vitro properties

Infectious crude sap that extracted from infected $H$. muticus L. leaves was used to determine the properties of the isolated virus. The thermal inactivation point (TIP), dilution end point(DEP) and longevity in vitro (LIV) at room temperature $\left(25-28^{\circ} \mathrm{C}\right)$ of the isolated virus were found to be $65^{\circ} \mathrm{C}, 10^{-4}$ and 4 days respectively.

Ultraviolet extinction spectra of partial purified virus

The concentration of virus preparation was estimated, it was $0.77 \mathrm{mg} / 100 \mathrm{~g}$ fresh leaves using spectrophotometric measurements at $260 \mathrm{~nm}$. The absorption ratio A260 / A280, A280 / A260 and Amax /Amin were 1.093, 0.914 and 1.072 respectively as represented in Table 2 .

TABLE 2. Absorption spectrum of partial purified virus isolate .

\begin{tabular}{|c|c|c|c|c|c|}
\hline Amax (nm) at & Amin (nm) at & $\mathbf{A 2 6 0} / \mathbf{A 2 8 0}$ & $\mathbf{A 2 8 0} / \mathbf{A 2 6 0}$ & Amax/Amin & Yield mg / 100g \\
\hline 267 & 249 & 1.093 & 0.914 & 1.072 & 0.77 \\
\hline
\end{tabular}

Morphological characters

Electron microscopic examination of partial purified preparation of virus isolate demonstrated the presence of flexuous filamentous virions with $1440 \mathrm{~nm}$ long and $14.3 \mathrm{~nm}$ wide as shown in Fig. 3.

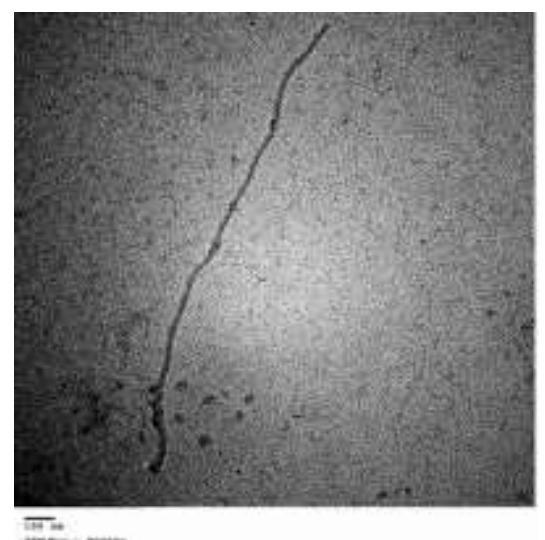

Fig 3. TEM micrograph of partial purified virus showing long filamentous virion negatively stained with $2 \%$ phosphotungestic acid. Bar represents 100 nm, 80.000 X.

Molecular characterization of virus isolate

PCR amplification of the coat protein gene of the virus isolate

The total RNA prepared from infected henbane leaf was reverse transcribed by RevertAid First Strand cDNA Synthesis Kit and minus sense of each three different primers for coat protein gene of henbane mosaic virus (HMV), Potato virus $\mathrm{X}(\mathrm{PVX})$ and Potato virus $\mathrm{Y}(\mathrm{PVY})$. The resulting complementary DNA 
(cDNA) was amplified by adding each forward (+) specific primer. Only HMV primers produce amplified PCR product as shown in Fig 4. The amplified cDNA was in the expected size calculated $(\sim 778 \mathrm{bp})$. The authenticity of the resulting PCR product $(\sim 778 \mathrm{bp})$ was verified by DNA sequencing after purification of DNA fragment from agarose gel using rapid and efficient kit.

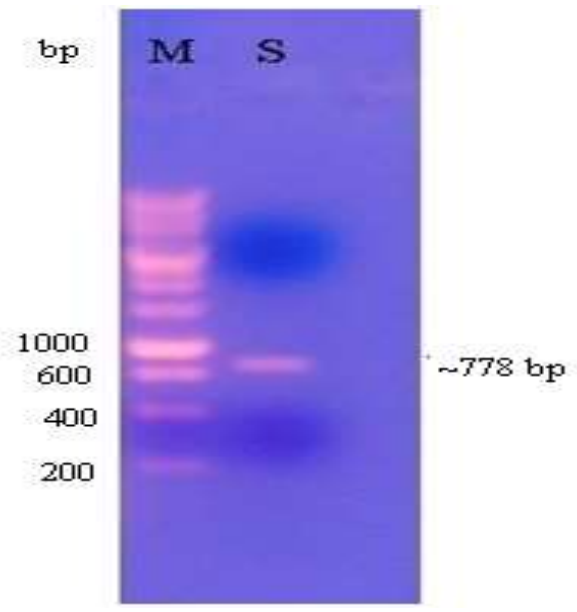

Fig. $4.1 \%$ agarose gel electrophoresis showing the PCR product of isolated virus coat protein gene using henbane mosaic virus specific primers forward (30F20) \& reverse (788R20). Total RNA was extracted from henbane leaves infected with virus isolate. The right arrow pointed to the amplified PCR product ( $778 \mathrm{bp}$ ). Lane 1, Molecular weight DNA ( 200 bp ladder) and Lane 2, amplified PCR product(S).

Automated DNA sequencing.

Partial nucleotide sequence of the virus coat protein gene of the current study revealed a size of $778 \mathrm{bp}$. The $778 \mathrm{bp}$ was aligned with four published sequences of potyviruses:

1. AM184113 (Hungary-isolate) Henbane mosaic virus partial gene for polyprotein-PHYS/H isolate was reported by Salamon et al. (2008).

2. A Y166867 (American-strain) Potato virus Y strain N isolate was reported by Nie \& Singh (2003).

3. EU482153 (Foggia-isolate) Potato virus Y isolate Foggia was reported by Mascia et al. (2010).

4. KF850513 (M3-isolate) Potato virus Y isolate M3 was reported by QuinteroFerrer et al. (2014) as shown in Fig 5A.

In the present study, the Egyptian potyvirus isolate under study was published in GenBank under accession number KM497011.

Moreover, the homology tree of partially sequenced coat protein gene (KM497011) revealed relatively high degree of similarity (62\%) with the previous four potyviruses. Multiple sequencing alignments were generated using DAMANversion 5.2.9 (Fig. 5B).

Egypt. J. Bot., Vol. 56, No. 2 (2016) 
AM184113 KM4997011 AY166867 EU482153 KFB50513 Consensus KM1497011 AY166867 EU482153 KFB50513

Consensus

AM184113 KMM497011 AY1 66867 EU482153

KF850513 Consensus

AM184113 KM497011 AY166867

EU482153 KFB50513 Consensus

AM184113 KM1497011 AY166867 EU482153 KF850513 Consensus

AM184113 ICM497011 AX166867 एण482153 KE Consensus

AM184213 KOM497011 AY 166867 EU482153 REB50513 Consensus

AM2 4213 KOM497011 AY 166867 EU482153 KF850513 Conaenaus

AM184113 RM1497011 AY166867 EU482153 KF 850513 Consensus

AM184113 KM4997011 AY 166867 EU482253 REB 50513 Conaenaua
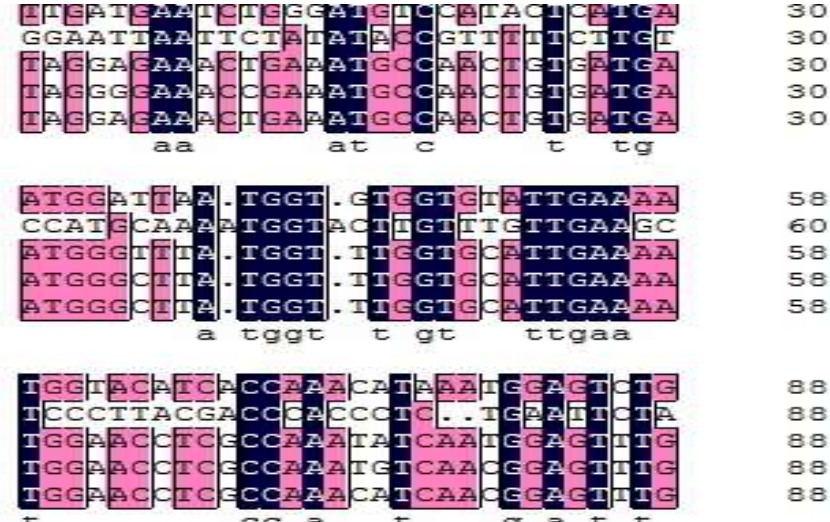

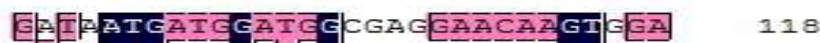

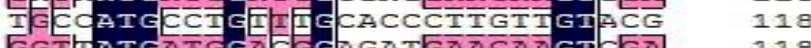

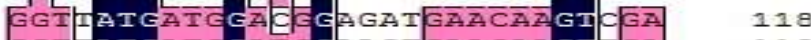
GGTIATGATGGATGGAAGTGAACAAGTIEA 118

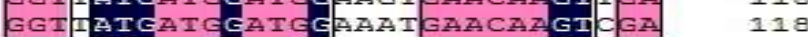

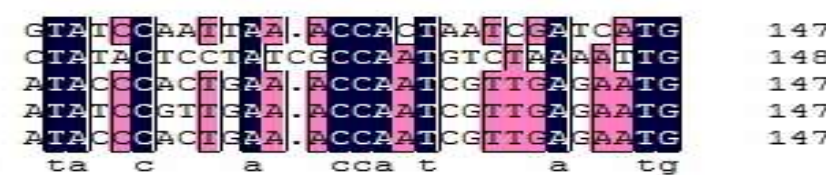

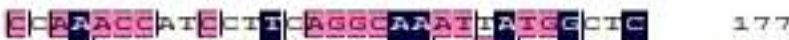

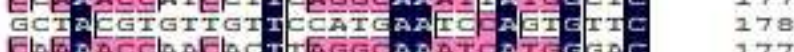

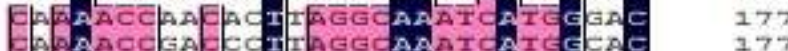

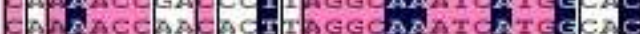
a

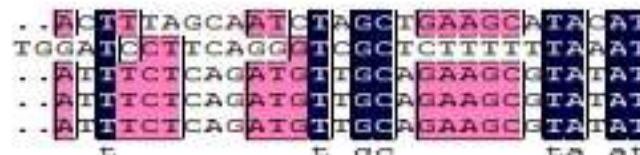

205

208

205

205

205

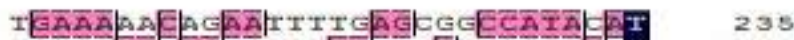

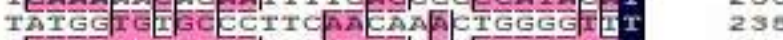

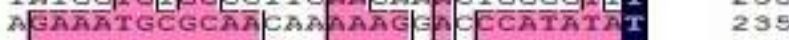
AGAAATGCGCAATAATAAG AGAAATGCGCAACAAEAAG
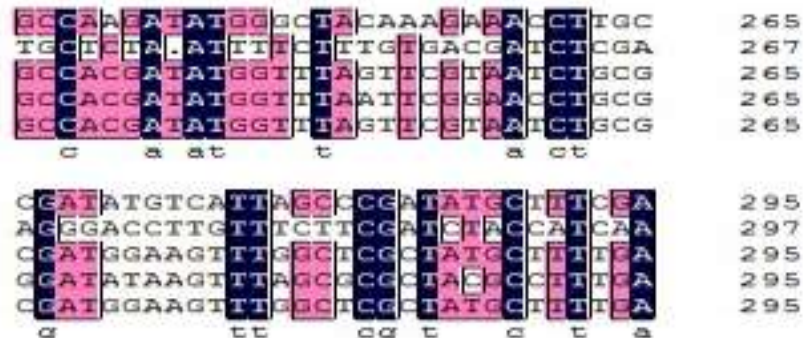

Egypt. J. Bot., Vol. 56, No. 2 (2016) 

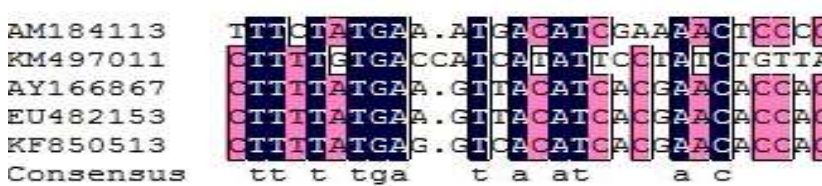

AY 166867

KF850513

consensus

ccd和 GCA

$\operatorname{AM1} 84113$

KR1497011

AY166867

EU482153

KF8 50513

Consensus

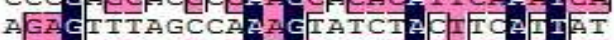

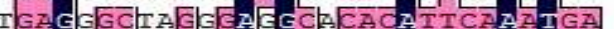

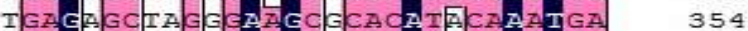

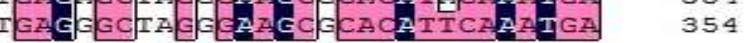

AM184113

KM1497012

AY166867

EU482153

KF850513

Consensus

AM184113

KR1497011

AY 166867

EU482153

KF850513

Consensus

AM184113

KR1497011

AY166867

EU482153

KF850513

Consensus

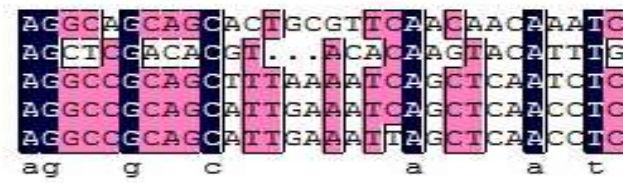

384

384

384

384

384

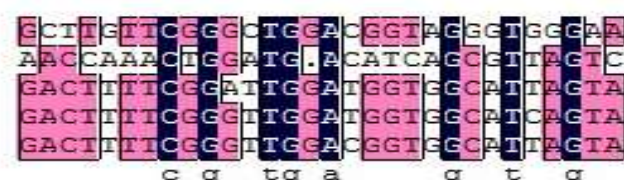

414

413

414

414

414

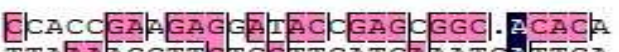

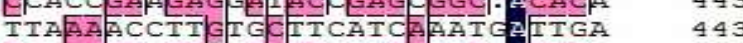

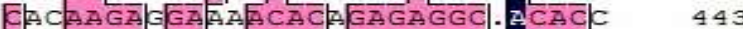
EACAAGAGGAMACACAGAGAGGC.ACACE 443

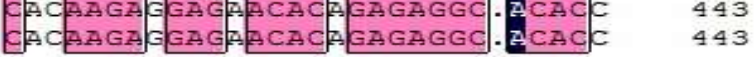

AM184113

KOM497011

A 766867

एu4 02153

KEBSO513

Consensus

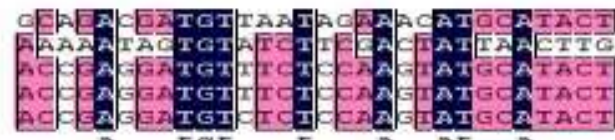

473

473
473

473

473

AM184113

KM4 $970 x$

AX166067

एU48215

KF850513

consersaus

AM184113

RCM497011

AY16686.

EU48215

EU48215

Conaenaua

AM1841.3

KM497011

AY166867

रण482359

KEDSOS13

Consensues

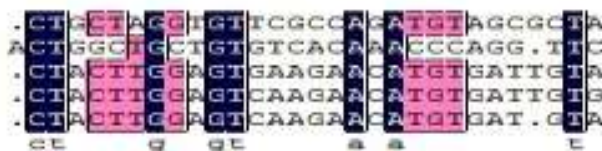

502

502

502

502

501

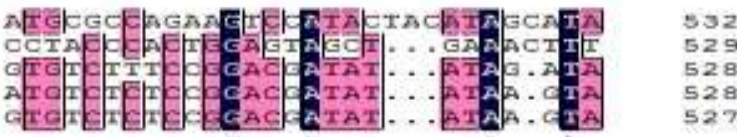

AM184123

KM49701

AY16 6857

EU482153

KEB 50513

Consenaus

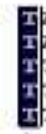
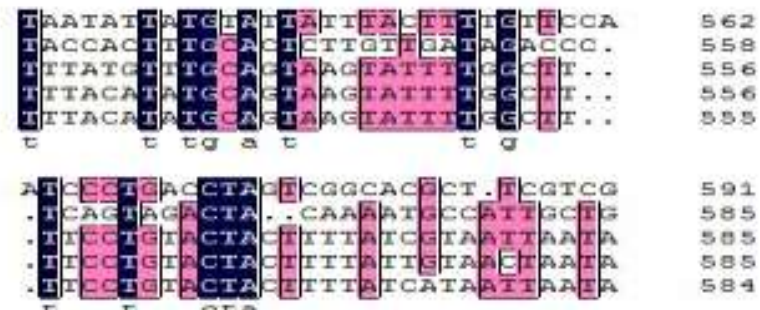

Egypt. J. Bot., Vol. 56, No. 2 (2016) 


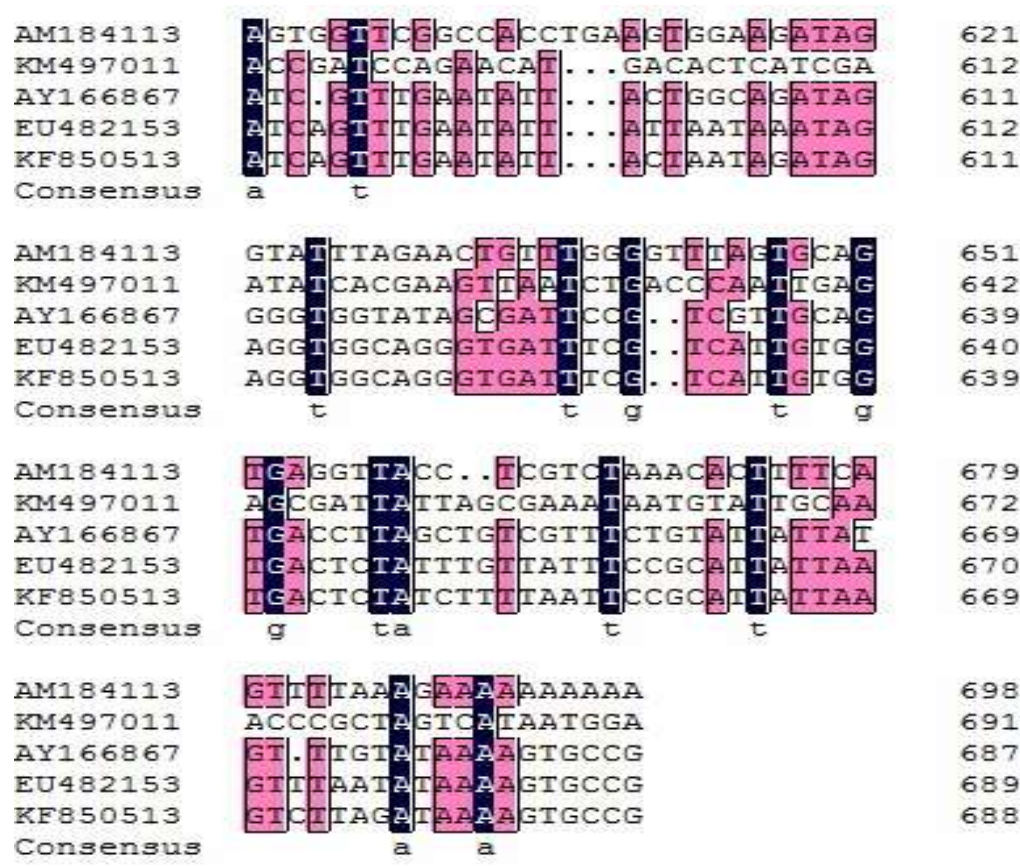

Fig. 5A. Multiple sequence alignment of partial $\mathrm{CP}$ gene sequence of the current studied virus (KM497011) with four different isolates of potyviruses. Accessions numbers indicated above were as following: AM184113: Henbane mosaic virus partial gene for polyprotein-PHYS/H isolate, AY166867: Potato virus $Y$ strain $N$ isolate,EU482153: Potato virus $Y$ isolate Foggia, KF850513: Potato virus Y isolate M3.
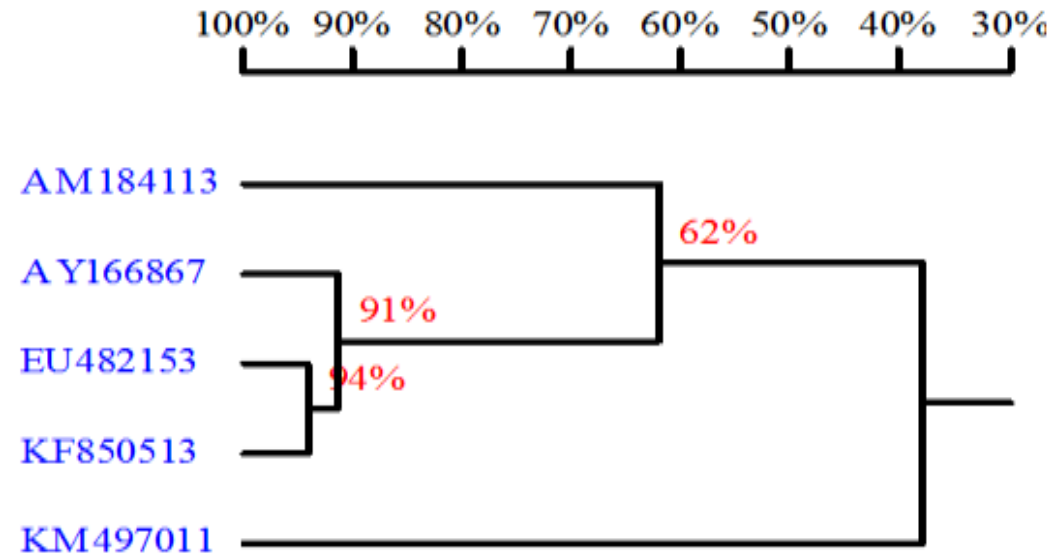

Fig 5 B. Homology tree of partial CP gene sequence of the virus (KM497011) with a previous four different isolates of potyviruses. 
The homology tree of KM497011 revealed some degree of similarity ( 62\%) with other four potyviruses isolates.

\section{Discussion}

The viruses of the Potyviridae infect wide range of economical crops (Edwardson, 1974). Severe mosaic, rugosity, blistering and malformation exhibited on the leaves of naturally infected henbane plants (Hyocyamus muticus L.).Fifteen diseased samples were collected in January 2013 from the Experimental Farm of Faculty of Pharmacy, Cairo University

Diagnostic susceptible hosts for viruses -infecting henbane were Chenopodium amaranticolor (chlorotic local lesion with necrotic center), Datura stramonium, Nicotiana tabacum cv. White Burley and N. tabaccum cv. Sumsun (mosaic symptoms), $N$. glutinosa (necrotic lesions followed by systemic mosaic), $N$. rustica (chloresis followed by leaf malformation), on Solanum demissum and $S$. tuberosum (necrotic local lesions). No symptoms appeared on Ch. quinoa and Cucumis sativus. These results are in agreement with those obtained by Lovisolo and Bartels (1970) and Salamon (1989) who found that the diagnostic susceptible host species for HMV were D. stramonium (severe mosaic), $N$. glutinosa, $N$. tabacum cvs. White Burley and Samsun (necrotic local lesions and then mosaic) while diagnostic insusceptible host species were Amaranthus ssp., C. sativus and Ch. quinoa. Also, Delgado-Sanchez and Grogan (1970) found that potato virus y may be confused with tobacco etch and henbane mosaic viruses, which produce somewhat similar symptoms and have similar host ranges. Tobacco etch virus infects D. stramonium and produces necrotic wilting of Tabasco pepper and etching of the tobacco leaves. Henbane mosaic virus occurs less frequently in the common hosts of tobacco etch and potato $\mathrm{Y}$ viruses; it can infect $D$. stramonium but not Tabasco pepper. While, Purcifull and Edwardson (1981) reported that the potato virus $\mathrm{X}$ infection for D. stramonium in the form of small chlorotic rings followed by mottling, veinal chlorosis or veinal necrosis but Salamon (1989) found that henbane mosaic virus infect $D$. stramonium in the form of severe mosaic. As far as the authors are aware, the obtained results are the first record for Egyptian potyvirus isolate from H. muticus. Hamilton (1932) and Horvath et al. (1988) isolated HMV from D. stramonium showing wilt disease. Govier and Plumb (1972) isolated HMV from Atropa belladonna L., D. inermis L., D. stramonium L., Hyoscyamus niger L., N. tabacum L., Physalis alkekengi L. and S. dulcamara L. plants.

Walkey (1991) reported that the importance of host symptom to applied plant virologist. The field symptoms give the first indication to identity of virus and in the laboratory the symptoms produced in a host plant range may be of considerable value. The nature and the severity of disease symptoms will determine the economic importance of a virus, in the terms of reduced quality and yield loss. 
Twenty seven species belong to six different families were used to determine the host range of the isolated virus using mechanical inoculation. The obtained results showed that 14 species reacted with different responses with virus is olate belonging to two families (Chenopodiaceae and Solanaceae). These results are in agreement with those obtained by Saha et al. (1997), contrary to our results Horvath et al. (1988) and Saha et al. (1997) could not detect HMV on Capsicum annuum and Saha et al. (1997) not detected HMV on Lycopersicon esculentum and Solanum spp. While, in the present study, virus isolate produce no symptoms on 13 plants belonging to six families (Asteraceae, Crucifrae, Chenopodiaceae, Cucurbitaceae, Fabacea and Solanaceae). These plants were Brassica alba, B. nigra, Ch. quinoa, C. sativus, Cucurbita pepo, Glycine max, $N$. tabaccum cv. Kg23, N. tabaccum cv. Italy, N. glauca, Phaseolus vulgaris, Vicia faba, Vigna unguiculata and Zinnia elegans. These results were disagreed with Horvath et al. (1988) who detected HMV on Ch. quinoa, C. sativus and Phaseolus vulgaris.

Matthews (1991) reported that stability of the virus TIP, DEP and LIV as measured by infectivity (often in crude extracts) was an important criterion in attempting to establish group of viruses, control virus distribution and elimination of viruses both in vitro and open fields. In the present study, TIP, DEP and LIV of virus is olate were $65^{\circ} \mathrm{C}, 10^{-4}$ and 4 days respectively. These results were relatively in agreement with those reported by Sheikh et al. (2012) recorded that a TIP of a potyvirus has been isolated from Wedelia trilobata plants in Aligarh district of state Uttar Pradesh (India) was between $55^{\circ} \mathrm{C}-60^{\circ} \mathrm{C}$, DEP was within $10^{-4}$ and LIV at $20^{\circ} \mathrm{C}$ was within $24 \mathrm{hrs}$. Delgado-Sanchez and Grogan (1970) showed that the TIP of PVY strains ranged between $52-62^{\circ} \mathrm{C}$, DEP was $10^{-2}-10^{-3}$ and inactivated within $48-72 \mathrm{hrs}$ at room temperature.

The concentration of virus preparation $0.77 \mathrm{mg} / 100 \mathrm{~g}$ fresh leaves using spectrophotometric measurements at $260 \mathrm{~nm}$. The UV spectral analysis of a nucleoprotein showed maximum and minimum absorptions were $267 \mathrm{~nm}$ and $249 \mathrm{~nm}$, respectively. The absorption ratio A260/A280, A280/A260 and Amax/Amin were 1.093, 0.914 and 1.072, respectively. These results were in agreement with obtained by Sheikh et al. (2012) who recorded that the purified potyvirus had been isolated from Wedelia trilobata plants in Aligarh showed the typical UV spectrum of a nucleoprotein with a maximum absorption at $260 \mathrm{~nm}$ and minimum absorption at $246 \mathrm{~nm}$. The A260 / A280 ratio was $1.21 \pm 0.04$.

The electron microscopy examination of partially purified preparation of the virus isolate demonstrated the presence of flexuous filamentous viruses with length of $1440 \mathrm{~nm}$ and width of $14.3 \mathrm{~nm}$. These results showed great difference with that reported by Horvath et al. (1988) and Saha et al. (1997).Our results strongly indicate that the isolated virus is a new Egyptian long flexuous potyvirus isolate. 
The molecular characters of the virus under study were investigated. Total RNA from virus infected Hyoscyamus muticus was extracted, and converted to cDNA and amplified via PCR reactions using specific primer: henbane mosaic virus (HMV), potato virus X (PVX) and potato virus Y (PVY).

SuccessfulPCR product was obtained by henbane mosaic virus "HMV" primer [30F20 (+) and788R20 (-)] using Taq-DNA polymerase. The annealing step was optimized by adjusting annealing temperature to $56^{\circ} \mathrm{C}$ for $45 \mathrm{sec}$. The size of the PCR products of specific amplified gene was $\sim 778 \mathrm{bp}$. The virus isolate under current study was published in Genbank with accession number KM497011.

However, the presumptive virus is olate under study showed some degree of similarity $(62 \%)$ with all the other potyviruses accessions (EU482153: Potato virus $\mathrm{Y}$ isolate Foggia, KF850513: Potato virus Y isolate M3, AM184113: Henbane mosaic virus partial gene for polyprotein-PHYS/H isolate, AY166867: Potato virus $\mathrm{Y}$ strain $\mathrm{N}$ isolate.

These results indicated that the virus under study might be either a new isolate of henbane mosaic virus (HMV) as showed by biological and morphological studies or might be a new isolate of potatao virus Y (PVY) since the nucleotide sequence similarity is relatively high $(88 \%)$ with PVY Foggia isolate.

Shukla and Ward (1989a \& 1989b) found that the N terminus was the only large region in the entire coat protein that is unique to potyviruses and contains virus - specific epitopes. Gambino et al. (2008) reported the importance of validating RNA extraction procedure for different sample matrixes and the ability of the extraction method to provide a suitable nucleic acid free of PCR inhibitors from each sample matrix because plants are known to contain a lot of possible PCR inhibitors such as polysaccharides.

In conclusion, the virus under study might be a new isolate of PVY or new isolate of HMV infecting Hyoscyamus muticus L. In order to confirm the identity of the virus isolate, further molecular investigations should be done emphasizing on the full viral genome sequences.

\section{References}

Delgado-Sanchez, S. and Grogan, R.G. (1970) Potato virusY.CMI./AAB. Descriptions of plant viruses. No. 37, CMI. /AAB, Kew, Surrey, England,4 pp.

Edwardson, J.R. (1974) Some properties of the potato virus Y group, "Florida Agricultural Experiment Stations monograph Series", 398 pp.

Gambino, G., Perrone, I. and Gribaudo, I. (2008) A rapid and effective method for RNA extraction from different tissues of grapevine and other woody plants. Phytochemical Analysis, 19, 520-525.

Egypt. J. Bot., Vol. 56, No. 2 (2016) 
Govier. D.A. and Plumb, R.T. (1972) Henbane mosaic virus. In: Descriptions of plant viruses. Common wealth Mycological Institute and Association of Applied Biologists. 95,1-4.

Hamilton, M.A. (1932) On Three New Virus Diseases of Hyoscyamus niger. Annals applied Biology.19, 550-567.

Horvath, J., Salamon, P., Wolf, I. and Kolber, M. (1988) Henbane mosaic potyvirus pathogenic to wild and cultivated potato. Potato Research., 31, 311-320.

King, A.M.Q., Adams, M.J., Carstens E.B. Lefkowitz E.J. (2011) Virus taxonomy. Ninth Report of The International Committee on Taxonomy of Viruses. Elsevier Academic press, London, San Diego,1326 pp.

Larsen, R.C., Kaiser, W.J., Wyatt, S.D., Buxton-Druffe, I.K.L. and Berger, P.H. (2003) Characterization of a new potyvirus naturally infecting chickpea. Plant Disease. 87, 1366-1371.

Lovisolo, O. and Bartels, R. (1970) On a new strain of Henbane mosaic virus from Physalis alkekengi. Phytopathology Z. 69, 189-201.

Malek, J.A., Shatsman, S.Y., Akinretoye, B.A. and Gill, J.E. (2000) Irreversible heat inactivation of DNase I without RNA degradation. BioTechniques. 29, 252-256.

Mascia T., Finetti-Sialer M.M., Cillo F. and Gallitelli D (2010) Biological and molecular characterization of a recombinant isolate of a potato virus $\mathrm{Y}$ associated with a tomato necrotic disease occurring in Italy. Journal of Plant Pathology. 92, 131-138

Matthews, R.E.F. (1991) "Plant Virology". $3^{\text {rd }}$ ed. Academic Press and Harcourt Brace Jovanovich, New York, NY, USA, 835 pp.

Nie, X. and Singh, R.P. (2003) Evolution of North American PVY (NTN) strain Tu 660 from local PVY(N) by mutation rather than recombination. Virus Genes. 26, 39-47.

Noordam, D. (1973) "Identification of plant viruses: Methods and Experiments". Centre for Agricultural Publishing and Documentation, Wageningen, $207 \mathrm{pp}$.

Purcifull, D.E. and Edwardson, J.R. (1981) Potexviruses. In: "Handbook of Plant Virus Infections and Comparative Diagnosis" (Kurstak E, Ed.). Elsevier and North Holland, Amsterdam, 627-693.

Quintero-Ferrer, A., Robles-Hernandez, L., Gonzalez-Franco, A.C., Kerlan, C. and Karasev, A.V. (2014) Molecular and biological characterization of a recombinant isolate of potato virus Y from Mexico. Archieves of Virology.159, 1781-1785.

Revers, F. and García, J.A. (2015) Molecular biology of poty viruses. Advances in Virus Research. 92, 101-199.

Riechmann, J.L., Lain. S . and Gracia. .J.A. (1992) Highlights and prospects of poty virus molecular biology. Journal of General Virology, 73, 1-16. 
Saha, S., Varma, A. and Jain, R.K. (1997) Biological and N-terminal serological properties of a strain of henbane mosaic virus causing mosaic disease of Datura metel Linn. Tropical Agricultural Research. 9, 346-357.

Salamon, P. (1989) Viruses and virus diseases of cultivated a4nd wild Solanaceae in Hungary, Natural hosts of cucumber mosaic virus (CMV). Novenyvedelem. 25, 97-109.

Salamon, P., Michaletzky, R. and Palkovics, L. (2008) Henbane mosaic virus in Hungary: Natural hosts, pathological variability and the first sequence data. Journal of Plant Pathology. 90 (2, Supplement), 437 pp.

Sheikh, M., Ashraf, M. and Mahmood, I. (2012) Biological and molecular detection of a virus infecting Wedelia trilobata (Linn.) Hitche (A Medicinal Herb). Journal of Plant Pathology and Microbiology. 3,1-4.

Shukla, D.D., Ward, C.W. and Bunt, A.A. (1994) The Potyviridae. C.A.B. International, Wallingford, UK, $516 \mathrm{pp}$.

Shukla, O.D. and Ward, C.W. (1989a) Structure of potyvirus coat proteins and its application in the taxonomy of the potyvirus group. Advances in Virus Research. 36: 273-314.

Shukla, O.D. and Ward, C.W. (1989b) Identification and classification of poty viruses on the basis of coat protein sequence data and serology. Archives of Virology. 106: 171-200.

Smith, K.H. (1972) “A Text Book of Plant Virus Diseases", $3^{\text {rd }}$ ed. Longman group Ltd. London, $684 \mathrm{pp}$.

Steere, R.L. (1956) Purification and properties of tobacco ringspot virus.Phytopathology . 46, 60-69.

Walkey, D.G.A. (1991) “Applied Plant Virology”, $2^{\text {nd }}$ ed. Chapman\& Hall, London, 71 p.

Yamamoto, H. and Fuji, S. (2008) Rapid determination of the nucleotide sequences of potyviral coat protein genes using semi-nested RT-PCR with universal primers. Journal of General Plantathlogy.74, 97-100. 


\section{دراسات بيولوجية و جزيئية علي عزلة فيروس البوتي المصرية

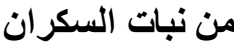

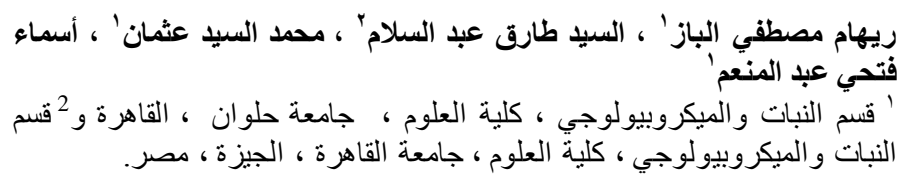

تم عزل فيروس بوتي جديد من نباتات السكران مصابة إصابة طبيعية وقد تم

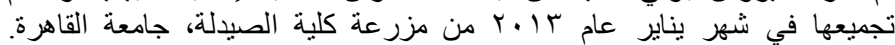

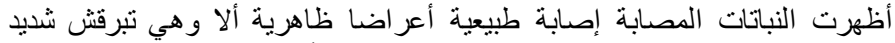

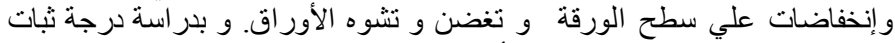

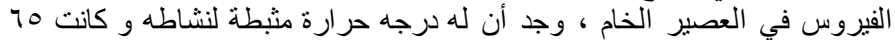

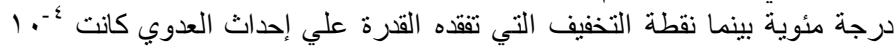

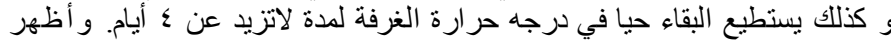

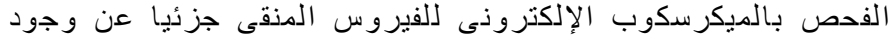

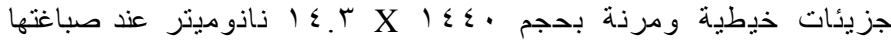

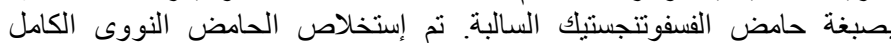
RNA لنبات السكران المصاب بالفيروس. أوضح التئه التتابع النيوكلتيدي المقارن

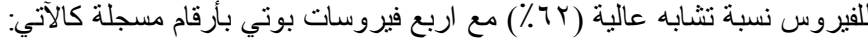

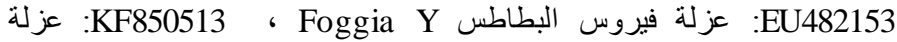
فيروس البطاطس M3 Y M3 ، M184113: الجين الجزئي لعديد البروتينات

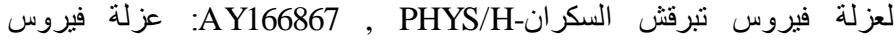
البطاطس N Y Y. وتم تسجيل العينة في بنك الجينات برقم مسجل KM497011. 